Madrygal. Revista de Estudios Gallegos

ISSN: 1138-9664

\title{
Narrativa
}

\section{Un cuarto baleiro}

\author{
Daniel Dapía Barral
}

Non podía ser un home, só un latexante despoxo animal, herdeiro bastardo dunha especie extinta; o seu desprezable fin. O home rabuñou o seu peito nu; talvez a súa pel que tremía pelo frío fose plástico reciclado dun computador obsoleto, viciado e sen memoria, e todo el unha mala versión non aprobada dun androide Enedd.

Espertou ao escoitar a unha muller chorando no cuarto do lado, laiándose con saloucos envelenados pola noite sen sono que parecían azoutar a súa memoria nunha dolorosa confesión a media voz. Sentiuna bater na parede que separaba os dous cuartos e espertou dubidando da certeza da noite.

-Señor, señor, segues con vida? - preguntou a muller-. Non te sinto respirar e sei que estás preto, trala parede. Non me atrevo a preguntar se estás vivo. Só podo ouvir estas palabras a correr coma animais salvaxes no interior do meu cranio: home, vida, silencio. Dime que estás vivo. Déixame escoitarte para non ouvirme durante un intre.

—Non sei quen es — respondeu o home con malhumor.

-O meu nome é o nome dunha flor que só vi en fotografías. As flores crecían na terra queimada na que hoxe están enterrados os nosos mortos.

O home ergueuse da cama ao ver reflectidas nas fiestras do edificio de en fronte as luces dos Seon, os visores da policía que percorrían as rúas examinando o interior das vivendas. Os frecuentes suicidios de suxeitos produtivos obrigaron ao Consello a reforzar as medidas de supervisión e censura das actividades dos cidadáns, promulgándose castigos para os que de calquera xeito ameazasen a seguridade e o plan de produtividade e consumo establecido polo $3^{\circ}$ Goberno do Consello. Os visores, provistos de sensores térmicos, vadiaban as rúas cada noite coma cans sen dono.

- O silencio rompeuse. Non estamos sós, outra vez. Agora sei que non te coñezo. Xamais escoitei a túa voz.

- Cala. Estamos outra vez en silencio. Queren isto para nós. Déixame durmir, teño que espertar en canto amenza para ir ao traballo.

O home tapou os ouvidos coas mans para non escoitar a muller do lado. O que mais desexaba naquel intre era berrar coma un animal até ficar sen alento e esquecer. Poder esquecelo todo.

-Onde estamos a vivir? Unha cama tras outra cama tras outra cama e xente igual a nós a morrer nelas en silencio. O corazón afogándonos. Non teño mans, non teño ollos, non teño peito, non teño ventre. Devoráronos.

-Estúpida! —rosmou o home.

O reprodutor hologramático continuaba acendido. Na versión do Sexus II da que dispuña podía escoller unha muller entre diversos parámetros de idade, raza e características físicas á que pedirlle unha ampla gama de xogos sexuais excluíndo o contacto. $\mathrm{O}$ home prendíao cada noite para finxir ter compaña e poder conversar con alguén. Fronte a el, esvaecida coma unha vaga lembranza, unha rapaza loura de faccións caucásicas quitábase a roupa unha e outra vez movendo os beizos sen que puidese escoitar nada dela, só o murmurio mecánico do reprodutor co que se durmía cada noite fitando sen pracer na rapaza que ría sen ruído ao pé da cama. 
Apagou o programa Sexus II e ficou ás escuras escoitando o silencio da rúa. Tras de si, afogado, o salouco da muller do cuarto do lado parecía o inútil esforzo dun insecto por mudar noutra cousa, un verme que non podendo escarvar mais na súa propia dor soña con converterse en bolboreta para saír voando lonxe da memoria e da súa presenza.

-En que pensas cando espertas? Escóitote camiñar polo cuarto tirando coas cousas.

-Non tiro nada. As cousas caen ao tropezar con elas, sen saber a onde ir.

-Escóitote chorar.

-Non choro!

-Polas noites choro e escóitote chorar.

-Choro para tentar durmir, só por iso. Penso que así o fan os nenos. Non choro porque estea triste. Choro para non pensar.

-En que pensas cando queres deixar de pensar?

O home acendeu o programa de reprodución. Procurou entre os contidos dixitais arquivados un vídeo do seu avó, sendo un neno, pescando no río que percorría a aldea na que vivira a súa familia até a terceira guerra mundial, primeira da nova orde. Non coñeceu o seu avó, só lle entregaran pequenos vídeos borrosos e unhas poucas fotografías entre as pertenzas do seu pai cando lle comunicaron a súa morte no colexio para desprazados. Ese era o seu pasado: un disco duro con fotografías e vídeos familiares gravados con teléfonos móbiles antigos. Hai anos viaxou ao lugar onde estivo a aldea e só había un páramo negro e queimado. A canle do río, pese a choiva que caía cunha mansedume graxenta, era un leito de pedras escuras e oleosas onde quedaran esculpidos coma esqueletos os restos de ramas podres das árbores devastadas da ribeira.

-Esperto e teño dúbidas. Durante o día compórtome coma os demais; ao lonxe, se puidese verme camiñando ao traballo, non podería diferenciarme de calquera outro co uniforme da fábrica. Iso é o que penso. Falamos de calquera cousa sen deixar de camiñar; calquera cousa sen importancia coa que practicar a nova linguaxe Ceof, e somos capaces de rir até calar avergoñados cando un de nós se equivoca. É agradábel sentir o riso a nacer no peito e queimar na gorxa, até morrer, en silencio. Os demais fitan para nós recriminando que riamos. Nós tamén o facemos con eles, ofendidos cando os escoitamos rir. Ninguén quere problemas cos supervisores. Teñen razón. É máis agradábel camiñar en silencio, pensando tan só nos pequenos pasos que nos empurran cara ao traballo onde con estas mans pequenas e febles somos capaces de crear cousas tan importantes para o Consello, anacos de máquinas enormes que xamais poderemos ver. Traballar e comer e vivir pensando tan só no que estás facendo, en non trabucarte, en aproveitar o tempo do que dispós para a túa tarefa é agradábel e cómodo. Traballar até o cansazo e despois durmir sen sentir nada mais, até que entón esperto e teño dúbidas e xa non consigo durmir e agardo a que chegue o amencer para volver ao traballo onde todo é seguro. Creo que es ti quen me esperta. Sinto as túas mans a través da parede, tamén a túa calor. Escóitote chorar, rabuñarte, berrar coa voz calada por temor a ouvirte e esperto por medo a que sexa eu quen chore, a que esquecese deixar de chorar querendo ter o sono plácido dun neno.

-Es un mentireiro. Espertas e ficas en silencio; érgueste e comezas a camiñar cada vez mais rápido até que tropezas e caes ao chan, desesperado ao ver como pasa o tempo, e acendes o Sexus II e mastúrbaste vendo algunha muller do programa até chorar co seme a escorrer pola man, sentindo que non tes nada en ti agás o baleiro. Choras porque no silencio do cuarto non podes facer outra cousa que pensar e bater coa cabeza na parede.

-Que podo facer? Que crees que fan os outros? Todos están cansos de camiño ao traballo, sen durmir, desexando chegar á fábrica para esmorecer e regresar despois a casa e caer na cama e durmir sen sentir nada, sen sono, igual que os mortos, mais vive no meu cerebro o pensamento, semellante a un lóstrego, e teño medo de que o descubran antes de que consiga afogalo.

\section{- Choras porque es un home!}

Unha sombra amarelenta esmagou a roupa de traballo tirada no chan. Os visores da policía parecían ollos flotantes e sen vida coma os dun cabalo morto. Un destello dixital no interior do visor advertía do minucioso rexistro que estaban a facer do seu cuarto. Acendeu a luz. Só había roupa engurrada e un libro electrónico na mesiña de noite cargado coa gramática e a historia promulgada polo Consello na que se eludía o pasado converténdoo en falsa mitoloxía. Repetiu en alto as últimas palabra que aprendera en idioma Ceof: Exter, Nada; Fello, 
Soño; Eleno, Humán; Morell, Desexo; e ollou para o reloxo antes de pechar os ollos sabendo que xa non lle quedaba tempo para durmir.

Soaron as alarmas na rúa. Sen a gradación do amencer, centos de soles artificiais iluminaron o Distrito XII. Canso, o home vestiuse para ir ao traballo. No corredor, ao unirse aos demais homes que en resignado silencio se dirixían coma el á fábrica coa ollada esvarando no chan, abriu a porta do cuarto do lado sen atopar nada no seu interior que fixese pensar que alí vivise un ser humano. 